\title{
Colloidal stability and hot filtration test of residual fuel oils based on visbreaking and ebullated bed residue $\mathrm{H}-\mathrm{Oil}$ hydrocracking
}

\section{Dicho Stratiev* and Ivelina Shishkova}

LUKOIL Neftohim Burgas AD,

Burgas, 8104, Bulgaria

Email: stratiev.dicho@neftochim.bg

Email: Shishkova.Ivelina.K@neftochim.bg

*Corresponding author

\section{Natalia Ivanova, Anife Veli, Radoslava Nikolova and Magdalena Mitkova}

Burgas University ‘Assen Zlatarov’,

1, Prof. Yakimov str., Burgas, 8000, Bulgaria

Email: nataliq_toshkova_ivanova@abv.bg

Email: anife_veli@abv.bg

Email: radoslava nikolova@btu.bg

Email: mmitkova@btu.bg

\section{Kiril Stanulov}

University of Chemical Technology and Metallurgy,

8, Kliment Ohridski Blvd., Sofia, 1756, Bulgaria

Email:stanulov@uctm.edu

\section{Georgy Argirov}

LUKOIL Neftohim Burgas AD,

Burgas, 8104, Bulgaria

Email: Argirov.Georgi.S@neftochim.bg

\section{Dobromir Yordanov}

Burgas University ‘Assen Zlatarov',

1, Prof. Yakimov str., Burgas, 8000, Bulgaria

Email: dobromirj@abv.bg

\section{Ekaterina Nikolaychuk}

LUKOIL Neftohim Burgas AD, Burgas, 8104, Bulgaria

Email: Nikolaychuk.E@neftochim.bg 
Abstract: Six H-Oil-based residual fuel oils, two H-Oil atmospheric tower bottom products, two $\mathrm{H}$-Oil vacuum tower bottom products, one visbreaker-based residual fuel oil, and three different straight run vacuum residual oils were studied in this work. The colloidal stability parameters S-value (ASTM D7157), and separability number (ASTM D7061), along with SARA-based colloidal instability index, and the solubility parameters of asphaltene and maltene fractions of the studied residual oils were tested to correlate with the residual oil sediment content. It was found that none of the colloidal stability parameters correlated with the residual oil sediment content, while correlations were found between the different colloidal stability parameters. This study has shown that only the residual oil samples whose S-value has been at minimum of 1.375 kept their sediment contents without change with the course of time. [Received: August 1, 2016; Accepted: December 4, 2016]

Keywords: residue colloidal stability; S-value; separability number; solubility parameters; hot filtration test; SARA; colloidal instability index; CII.

Reference to this paper should be made as follows: Stratiev, D., Shishkova, I., Ivanova, N., Veli, A., Nikolova, R., Mitkova, M., Stanulov, K., Argirov, G., Yordanov, D. and Nikolaychuk, E. (2019) 'Colloidal stability and hot filtration test of residual fuel oils based on visbreaking and ebullated bed residue H-Oil hydrocracking', Int. J. Oil, Gas and Coal Technology, Vol. 20, No. 2, pp.169-188.

Biographical notes: Dicho Stratiev is the Chief Process Engineer in the LUKOIL Neftohim, Burgas, Bulgaria. He is responsible for operation guidance of all refinery units, troubleshooting support and unit performance optimisation. He is an author of more than 190 technical papers.

Ivelina Shishkova is the R\&D Department Manager at the Lukoil Neftochim Bourgas, Bulgaria. She is an author of more than 70 technical papers.

Natalia Ivanova is a $\mathrm{PhD}$ student at the Professor Dr. Assen Zlatarov University. She interned at LUKOIL Neftohim Burgas refinery as part of the Process Engineering Department.

Anife Veli is a PhD student at the Professor Dr. Assen Zlatarov University. She interned at LUKOIL Neftohim Burgas refinery as part of the Process Engineering Department.

Radoslava Nikolova is a PhD student at the Professor Dr. Assen Zlatarov University. She interned at LUKOIL Neftohim Burgas refinery as part of the Process Engineering Department.

Magdalena Mitkova is an Associate Professor and Rector of the Burgas University Assen Zlatarov. She teaches in the organic chemistry technologies department in organic synthesis. She holds an MS and $\mathrm{PhD}$ in Organic Chemistry Engineering from the Burgas University Assen Zlatarov.

Kiril Stanulov is an Associate Professor, he received his $\mathrm{PhD}$ in the University of Chemical Technology and Metallurgy - Sofia, Bulgaria. He teaches in the Synthesis and Fuels Department in the field of oil refining and lubricants.

Georgy Argirov is a Chief Process Engineer at Ebullated Bed Residue H-Oil Hydrocracking Unit in the LUKOIL Neftohim, Burgas, Bulgaria. 
Dobromir Yordanov is an Associated Professor at the Burgas University Assen Zlatarov. He teaches in the Industrial Technologies and Management Department in the field of technology of fossil and synthetic fuels and quality management. He is the author of more than 50 technical papers.

Ekaterina Nikolaychuk is the Process Engineer in the Chief Process Engineer Department at LUKOIL Neftohim, Burgas. She graduated as Chemical Engineer at Ufa State Petroleum Technical University.

\section{Introduction}

The heavy oil conversion processes determine the economics of the modern oil refining, because of their capability to convert the low value black oils into high value transportation fuels and feedstocks for petrochemical industry. The higher the heavy oil conversion the higher the oil refining profitability is. Unfortunately, the conversion level in most residue conversion processes is limited by the colloidal instability of the unconverted residual oil. The colloidal stability deterioration and increasing of the soft coke like sediment content in the unconverted residual oil during thermal conversion of residual oils has been documented in several studies (Bartholdy and Andersen, 2000; Deng et al., 2011; Gawel et al., 2005; Higuerey et al., 2001; Li et al., 1999; Matsushita et al., 2004; Marafi et al., 2005; Rahimi et al., 1997; Robert et al., 2003; Rogel, 1998; Tojima et al., 1998; Wang et al., 2009; Zerlia and Pinelli, 1993; Zhang et al., 2006). The increased sediment content in the unconverted residual oil has impact on the quality of the finished residual fuel oil product, that is produced from the residue conversion unit unconverted residual oil and the added to it cutter stocks. This quality has been reported to affect the appearance of combustion problems in the marine engines, which employ residual fuel oils (Shimizu et al., 2000). That is why the sediment content in the residual fuel oils which can be used as marine fuels is specified at not higher than $0.1 \%$ as total sediment existent (TSE), total sediment accelerated (chemical aging with hexadecane; TSA), and total sediment potential (thermal aging; TSP). It was found that the colloidal parameter S-value of thermally cracked residual oils was related to the hot filtration test value (sediment content) (Stratiev et al., 2014b). Wiehe (2004) postulated that the region in which sedimentation and fouling appears is when the ratio between solubility bending number and the insolubility number of the residual oil is less than 1.4 (especially less than 1.3) (ASTM D7157, 2012a). The ASTM D7157 measured S-value actually presents the ratio between solubility bending number and the insolubility number. That is why the LUKOIL Neftohim Burgas (LNB) visbreaker unit severity was controlled by measuring S-value of the unconverted visbroken residue (Stratiev et al., 2015). The S-value minimum for the unconverted visbroken residue was set at 1.43 , to provide stable and reliable production of finished fuel oil with sediment content lower than the specified $0.1 \%$. Unfortunately, this strategy seems difficult to follow for the higher residue conversion processes like the ebullated bed residue H-Oil hydrocracking because at conversion higher than $40 \%$ during processing Urals vacuum residue the S-value gets lower than 1.3 (Stratiev et al., 2016b). However, the aim of the H-Oil residue hydrocracker is to operate at higher conversions (Stanislaus et al., 2005). It was found that the control of the sediment content in the finished residual fuel oil based on the 
vacuum residue H-Oil hydrocracking is extremely difficult for lack of instrument similar to that used in the visbreaker (S-value measurement) to govern reaction severity. Moreover, the property of the residual fuel oil based on the vacuum residue H-Oil hydrocracking that was most difficult to control was TSP (hot filtration test after thermal aging), which requires more than 24 hours to perform according to the IP 390 Procedure A (International Petroleum Test Methods, 2011). Therefore, if a disturbance in the TSP of the H-Oil unconverted vacuum residue occurs, it can be detected after more than 24 hours. During this period, off-spec residual fuel oil may be produced. In order to understand which residual fuel oil property should be controlled to avoid production of residual fuel oil with TSP higher than $0.1 \%$ fourteen residual fuel oils were investigated in this work. Six H-Oil-based residual oils having different sediment content obtained during processing of different feeds at different severity in the LNB H-Oil residue hydrocracker, one H-Oil pilot plant-based residual fuel oil, one residual oil based on the LNB visbreaker residue, two straight run vacuum residues obtained from different crudes, two unconverted vacuum residual oils from the LNB H-Oil residue hydrocracker, and two atmospheric residual oils from the LNB H-Oil hydrocracker were investigated in this study.

Several techniques have been used in the refining practice to control the colloidal stability of the unconverted residual oils from the heavy oil conversion processes: measurement of P-value (Andersen, 1999; Redelius, 2000), of S-value (Russell et al., 2010), C-value (Faina et al., 1995), and of separability number (SN) (ASTM D7061, 2012b). Both parameters P-value and S-value were found to correlate and the relation between them for the S-value range $1.05-2.5$ is given by the expression: $\mathrm{P}$-value $=0.446$ S-value +0.5345 (Sharpe, 2010). No correlation between C-value and the S-value of residual oils was found in the work of Stratiev et al. (2014a). To the best of our knowledge no data has been reported about existence of any relation between the S-value (P-value) and the SN. That was the reason for us to apply both S-value and SN for characterisation of the colloidal stability of the residual oils under study in this work. The aim of this paper is to search a relation of the TSE, and TSP to the colloidal stability parameters measured by both standards ASTM D7061, and ASTM D7157, SARA composition, and properties of the asphaltene and maltene fractions of the residual oils under study.

\section{Experimental}

\subsection{Materials}

The six H-Oil-based residual fuel oils were produced in the LNB refinery by blending the unconverted vacuum residual oils from the $\mathrm{H}$-Oil residue hydrocracker with fluid catalytic cracking (FCC) gas oils (LCO, HCO, and slurry). The content of the FCC cutter stocks in the finished residual fuel oil was about $30 \%$ of the finished residual fuel oil. The unconverted vacuum residual oils from the H-Oil residue hydrocracker were obtained during processing vacuum residue originated from $100 \%$ Urals crude oil, and from $70 \%$ Urals $/ 30 \%$ Basra Light crude oil blend at different severity and consequently at different conversion level (between 54 and 65\%). The visbreaker-based residual fuel oil was obtained by blending of visbreaker residue from the LNB visbreaker unit with FCC gas oils. The relative amount of the FCC cutter stocks in the finished visbreaker-based 
residual fuel oil was about $18 \%$. The straight run vacuum residual oils were obtained from the LNB crude distillation unit AVD-1 during processing 100\% Urals and the blend $70 \%$ Urals $/ 30 \%$ Basra Light. The atmospheric and vacuum residual oils from the LNB $\mathrm{H}-\mathrm{Oil}$ hydrocracker were obtained during processing vacuum residual oils from the crudes $100 \%$ Urals, and from the 70\% Urals/30\% Basra Light blend. Description of the studied residual oil samples is presented in Table 1.

Table 1 Designation of the residual fuel studied in this work and description of the way how they were obtained

\begin{tabular}{|c|c|}
\hline Sample title & Description \\
\hline H-Oil FO, 16.02 .16 & $\begin{array}{l}\text { This fuel oil sample was produced from H-Oil unconverted VTB, } \\
\text { during processing a vacuum residue oil (VRO) blend of } 95 \% \text { Urals } \\
\text { and } 5 \% \text { Kazakh crudes, and addition of about } 35 \% \text { FCC LCO, HCO, } \\
\text { and slurry. The } 540^{\circ} \mathrm{C} \text { conversion in the H-Oil hydrocracker was } \\
\text { about } 60 \% \text {. }\end{array}$ \\
\hline H-Oil FO, 08.03.16 & $\begin{array}{l}\text { This fuel oil sample was produced from H-Oil unconverted VTB, } \\
\text { during processing a VRO blend of } 80 \% \text { Urals and } 20 \% \text { Basrah Light } \\
\text { crudes, and addition of about } 35 \% \text { FCC LCO, HCO, and slurry, and } \\
\text { some amount of straight run VRO. The } 540^{\circ} \mathrm{C} \text { conversion in the H-Oil } \\
\text { hydrocracker was about } 65 \% \text {. }\end{array}$ \\
\hline VB FO, 05.15 & $\begin{array}{l}\text { This fuel oil sample was produced from visbreaker unconverted ATB, } \\
\text { during processing a } 100 \% \text { Urals VRO, and addition of about } 18 \% \\
\text { FCC LCO, HCO, and slurry. The } 540^{\circ} \mathrm{C} \text { conversion in the visbreaker } \\
\text { was about } 30 \% \text {. }\end{array}$ \\
\hline $\begin{array}{l}\text { H-Oil IFP } 70 \% / 30 \% \\
\text { HCO }\end{array}$ & $\begin{array}{l}\text { This fuel oil sample was obtained from a pilot } \mathrm{H}-\mathrm{O} \text { - il plant, during } \\
\text { processing a } 100 \% \text { Urals VRO at } 540^{\circ} \mathrm{C} \text { conversion of } 70 \% \text {, and } \\
\text { addition of } 30 \% \text { FCC HCO. }\end{array}$ \\
\hline H-Oil PBFO, 24.12.15 & $\begin{array}{l}\text { This fuel oil sample was produced from H-Oil unconverted VTB, } \\
\text { during processing a } 100 \% \text { Urals VRO at a conversion of about } 60 \% \text {, } \\
\text { and addition of about } 20 \% \text { FCC LCO and HCO. }\end{array}$ \\
\hline H-Oil FO, 20.05.16 & $\begin{array}{l}\text { This fuel oil sample was produced from H-Oil unconverted VTB, } \\
\text { during processing a VRO blend of } 70 \% \text { Urals and } 30 \% \text { Basrah Light } \\
\text { crudes, and addition of about } 35 \% \text { FCC LCO, HCO, and slurry, and } \\
\text { some amount of straight run VRO. The } 540^{\circ} \mathrm{C} \text { conversion in the H-Oil } \\
\text { hydrocracker was about } 65 \% \text {. }\end{array}$ \\
\hline H-Oil PBFO, 6.11 .15 & $\begin{array}{l}\text { This fuel oil sample was produced from H-Oil unconverted VTB, } \\
\text { during processing a } 100 \% \text { Urals VRO at a conversion of } 65 \% \text {, and } \\
\text { addition of about } 15 \% \text { FCC LCO and HCO. }\end{array}$ \\
\hline Urals SRVR & $\begin{array}{l}\text { This sample is straight run VRO, obtained by laboratory TBP } \\
\text { distillation of } 100 \% \text { Urals crude }\end{array}$ \\
\hline H-Oil ATB 20.05.16 & $\begin{array}{l}\text { This sample is ATB obtained from the LNB H-Oil hydrocracker } \\
\text { during processing a VRO blend of } 70 \% \text { Urals, and } 30 \% \text { Basra Light } \\
\text { crudes. The } 540^{\circ} \mathrm{C} \text { conversion was } 65 \% \text {. }\end{array}$ \\
\hline H-Oil VTB 20.05.16 & $\begin{array}{l}\text { This sample is VTB obtained from the LNB H-Oil hydrocracker } \\
\text { during processing a VRO blend of } 70 \% \text { Urals, and } 30 \% \text { Basra Light } \\
\text { crudes. The } 540^{\circ} \mathrm{C} \text { conversion was } 65 \% \text {. }\end{array}$ \\
\hline H-Oil Feed 20.05.16 & $\begin{array}{l}\text { This sample is straight run VRO, obtained from the crude blend } 70 \% \\
\text { Urals / } 30 \% \text { Basrah Light }\end{array}$ \\
\hline
\end{tabular}


Table 1 Designation of the residual fuel studied in this work and description of the way how they were obtained (continued)

\begin{tabular}{ll}
\hline Sample title & Description \\
\hline H-Oil ATB 05.11.15 & $\begin{array}{l}\text { This sample is ATB obtained from the LNB H-Oil hydrocracker } \\
\text { during processing a VRO from } 100 \% \text { Urals crude. The } 540^{\circ} \mathrm{C} \\
\text { conversion was } 65 \% .\end{array}$ \\
H-Oil VTB 05.11.15 & $\begin{array}{l}\text { This sample is VTB obtained from the LNB H-Oil hydrocracker } \\
\text { during processing a VRO from } 100 \% \text { Urals crude. The } 540^{\circ} \mathrm{C} \\
\text { conversion was } 65 \% .\end{array}$ \\
H-Oil Feed 05.11.15 & $\begin{array}{l}\text { This sample is H-Oil feed for the LNB H-Oil unit during processing in } \\
\text { the LNB refinery of } 100 \% \text { Urals crude. }\end{array}$ \\
\hline
\end{tabular}

\subsection{Methods}

The hydrocarbon group composition (SARA) of the 14 studied residual oils was measured. This data was determined by the use of liquid adsorption chromatography on silica gel following the procedure: The sample oil in an amount of about $8 \mathrm{~g}$ is diluted in $\mathrm{n}$-hexane in the ratio 1:3 and charged to a glass percolation column containing $80-85 \mathrm{~g}$ silica gel. After the whole sample quantity soaks, the silica gel $350-450 \mathrm{ml}$ of n-hexane is charged to the column for desorption of saturates, $200 \mathrm{ml}$ of benzene (98.5-99.9\%) for desorption of aromatics and $200 \mathrm{ml}$ ethanol (99.7\%)-benzene mixture 50 to 50 by volume for desorption of resins. The solvents are completely removed from the recovered n-hexane, benzene, ethanol-benzene fractions by distillation and residues are weighed. The separation between saturate and aromatic fraction was quantified by the use of refractive index as described in Stratiev et al. (2008). The resins content is determined on the base of the balance. The whole procedure is described in Stratiev et al. (2016a) in more details. Densities of the asphaltene and maltene fractions of the studied residual oils were measured indirectly from the densities of a series of solutions of asphaltenes and maltenes in toluene at different concentrations (Sadeghi-Yamchi, 2014). If the solutions are regular at low asphaltene and maltene concentrations, the density of the solution is related to the density of its constituents as follows:

$$
\frac{1}{\rho_{M}}=\frac{1}{\rho_{T}}+\left(\frac{1}{\rho_{\text {Asphaltene(Maltene) }}}+\frac{1}{\rho_{T}}\right) w_{\text {Asp.(Malt.) }}
$$

where

$\rho_{M}$ density of the mixture, $\mathrm{g} / \mathrm{cm}^{3}$ at $15^{\circ} \mathrm{C}$

$\rho_{T}$ density of the toluene, $\mathrm{g} / \mathrm{cm}^{3}$ at $15^{\circ} \mathrm{C}$

$\rho_{\text {Asphaltene(Maltene) }}$ density of the asphaltenes (maltenes), $\mathrm{g} / \mathrm{cm}^{3}$ at $15^{\circ} \mathrm{C}$

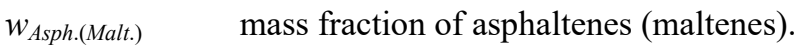

When the specific volume of the mixture is plotted versus asphaltene (maltene, residual oil) mass fraction, the asphaltene (maltene, residual oil) density is calculated as follows:

$$
\frac{1}{\rho_{M}}=b+a w_{\text {Asp.(Malt. })}
$$




$$
\begin{aligned}
& b=\frac{1}{\rho_{T}} \\
& a=\left(\frac{1}{\rho_{A}}-\frac{1}{\rho_{T}}\right) \\
& \rho_{A}=\frac{1}{a+b}
\end{aligned}
$$

where $a$ is the slope and $b$ is the intercept of the plot.

Solutions of asphaltene in toluene at concentrations up to an asphaltene mass fraction of $3 \%$ were prepared. Solutions of maltenes in toluene at concentrations up to a maltene mass fraction of $6 \%$ were prepared. The same procedure was applied for measurement of the densities of the residual oils under study. This way of acting was selected to avoid possible errors in measurement of the densities of the investigated residual oils. It was documented in our previous work that errors could be registered in measurement of residual oil density if no dilution with high aromatic solvent is applied (Stratiev et al., 2016c). Figure 1 presents graphs of the relation of the specific volume of the blend toluene-asphaltene (maltene, residual fuel oil) to the concentration of the asphaltenes (maltenes, residual fuel oil). By the use of the values of the intercept and the slope and equation (5) densities of the asphaltenes, the maltenes, and the residual fuel oils under study were determined.

The colloidal stability parameters of the studied residual oils S-value (intrinsic stability), Sa (peptisability or ability of the asphaltenes to remain in colloidal dispersion. $\mathrm{Sa}$ is related to the solubility of the asphaltenes, the length and number of the aromatic chains), and So (peptising power of oil is the 'aromatic' equivalent of the oil; it is a measure of the solvency power of the oil with respect to asphaltene solubility) were measured by the use of a modification to ASTM D7157-05 as described in Bartholdy and Andersen (2000). Stratiev in his work showed that according to the oil compatibility model of Wiehe oils whose $S$-value $\geq 1.4$ should be considered colloidal stable, which are not prone to form sediments (Stratiev et al., 2016b). The colloidal stability parameter SN of the investigated residual oils was measured in accordance with the ASTM D7061. According to ASTM D7061, oils whose SN is between 0 and 5 have high stability reserve; SN between 5 and 10 have lower stability reserve, and SN higher than 10 have very low stability reserve and are prone to form sediments.

High temperature simulated distillation (HTSD) was used to measure the distillation characteristics of the investigated residual oils. It was performed in accordance with the standard ASTM D7169. The procedure employed for performance of the HTSD of the studied residual oils is described in Nikolaychuck et al. (2016).

Samples of the residual oils were analysed for their total existent sediment content or TSE (according to the procedures IP 375), TSP, measured in accordance with IP 390 Procedure A after thermal aging, and TSA, measured in accordance with IP 390 Procedure B after chemical aging (International Petroleum Test Methods, 2011). 
Figure 1 Specific volume versus mass fraction of asphaltene [(a) ATB 05.11.15], (b) ATB 05.11.15, and DAO [(c) fuel oil 20.05.16] in their blends with toluene (see online version for colours)

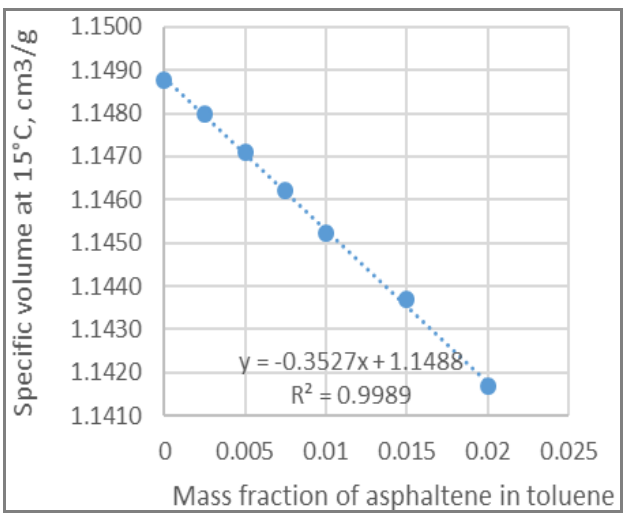

(a)

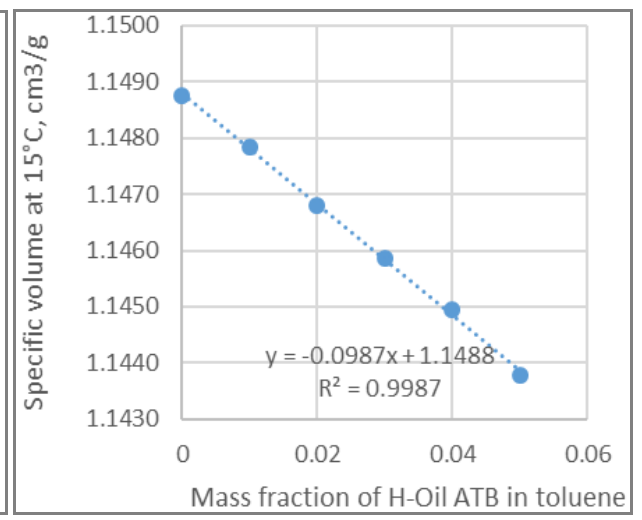

(b)

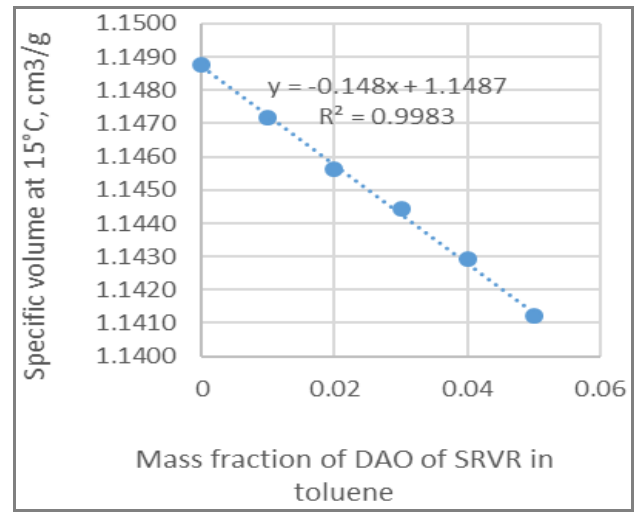

(c)

\section{Results and discussion}

The experience in the LNB refinery during employing the visbreaking as a vacuum residue conversion process has shown that if the colloidal stability of the unconverted atmospheric tower bottom (ATB) visbroken residue has S-value not lower than 1.43 the produced from it residual fuel oil is stable and does not change its TSE, TSA, TSP. With the introduction of the ebullated bed vacuum residue H-Oil hydrocracker in the LNB refinery in the second half of 2015 it was found that the residual fuel changed its TSE, and TSP with the course of time. Table 2 presents data for variation with time of TSE, and of TSP of some of the studied residual oils. It is evident from these data that the TSE, and TSP of the sample H-Oil FO, 16.02.16 increases three times TSE, and TSP for four months of storage of the sample at laboratory conditions (temperature $= \pm 25^{\circ} \mathrm{C}$ ). At the same time, the sample H-Oil FO, 08.03.16 is stable showing no variation in TSE, and TSP. The visbreaker-based residual fuel oil showed no variation of TSE, and TSP for a period of one year. The residual fuel oil sample prepared from $70 \%$ vacuum tower 
bottom product from a pilot $\mathrm{H}-\mathrm{O}$ il plant and 30\% FCC HCO showed no variation in the TSE, and TSP for a period of two years. The residual oil samples H-Oil ATB (H-Oil ATB) 20.05.16, and H-Oil VTB 20.05.16 (H-Oil vacuum tower bottom) showed more than double increase of the TSE only after two months of storage at laboratory conditions. Another event related to variation in sediment content of residual fuel oils based on the residue H-Oil hydrocracking during transportation was registered. During transportation of a cargo of residual fuel oil based on the residue H-Oil hydrocracking was found that the TSP increased from 0.1 to $0.3 \%$ for a week. The difference between the two measurements was beyond the reproducibility $=0.09 \%$ (IP 390) for that case, which suggested that this residual fuel oil was unstable. Then three other samples from three other cargos of residual fuel oil based on the residue H-Oil hydrocracking were analysed for a feasible variation of the sediment content determined by the three procedures: IP 375 (TSP); IP 390 Procedure A (TSP); and IP Procedure 390 Procedure B (TSA). The results of the analyses of these three samples are summarised in Table 3 . It is evident from these data that the TSE (hot filtration test) and TSA (hot filtration test after chemical aging with hexadecane) have almost the same values (A difference of $0.01 \%$ is within repeatability limits for both IP 375 and IP 390). This would mean that these residual oils are colloidal stable. However, the TSP of these samples was about three times as high as the TSE. Moreover, the values of cleanliness and compatibility numbers $=5$ determined by the spot test (ASTM D4740; A spot rating of number 3 or higher on a finished fuel oil by the cleanliness procedure indicates that the fuel oil contains excessive suspended solids) suggest that the three residual fuel oil samples are colloidal unstable. That is why we selected the 14 samples of the residual oils described in the introduction section to study the colloidal stability measured by the S-value, Sa, and So, and by the SN. Table 4 presents data for the physical and chemical properties and the colloidal stability of the 14 residual oils. It is evident from these data that the colloidal parameters S-value and SN vary between 1.136 and 3.749 (S-value), and between 0.4 and 18.1 (SN). The colloidal stability parameters Sa and So vary between 0.227 and 0.75 (Sa), and between 0.645 and 0.945 (So). Therefore, the residual oils under study are distinguished by a high variation in their colloidal stability. Another parameter used to evaluate the propensity of a residual oil to form sediments is the colloidal instability index (CII), introduced by Asomaning and Watkinson (2000). It is based on saturates, aromatics, resins, and asphaltenes [IP390 Procedure A (TSP), and IP Procedure 390 Procedure B (TSA)] compositional analysis of the oil to quantify the colloidal instability of oils (Evdokimov, 2010):

$$
C I I=\frac{(\text { Saturates }+ \text { Asphaltenes })}{\text { Aromatics }+\operatorname{Re} \sin s}
$$

The CII was found by Hong and Watkinson (2004) to correlate with the suspended asphaltene concentration of blends of Cold Lake vacuum residue and Athabasca ATBs with pure n-alkanes, a lube oil base-stock, a heavy vacuum gas oil and a resin-enriched fraction recovered from Cold Lake vacuum residue by supercritical fluid extraction and fractionation. Saleh et al. (2005) reported that the CII could be correlated with the concentration of insoluble solids when four crude oils used in Australia (Bach Ho, Gippsland, Cossack and Kutubu) were blended. Hong and Watkinson (2009) established that the CII was a useful empirical parameter for correlating fouling and precipitation results. Robert et al. (2003) reported that the unconverted ebullated bed residue 
hydrocracking H-Oil product CII correlated with the colloidal stability expressed by 'spot test result'. Watkinson (2007) postulated that when CII $<1.0$, the amount of resins plus aromatics is sufficient to maintain the asphaltenes in solution. The addition of saturates or removal of aromatics can shift the oil composition such that $\mathrm{CII}>1.0$, and asphaltenes will precipitate. The data in Table 4 show that CII of the studied residual oils vary between 0.34 and 0.75 . Therefore, according to Watkinson's postulate these residual oils should be considered colloidal stable.

Based on the data for measured densities of the asphaltene and maltene fractions and the correlations developed by Stratiev et al. (2016c), the H/C ratio of the asphaltene and maltene fractions was estimated by the expression:

$$
\frac{H}{C}=11.016 e^{-1.954 d_{4}^{20}}
$$

where

$\frac{H}{C}$ atomic $\frac{H}{C}$ ratio

$d_{4}^{20}$ relative density at $20^{\circ} \mathrm{C}$.

The conversion of $d^{15}$ in $d_{4}^{20}$ was performed by the use of the following equation:

$$
d_{4^{20}}=d_{15}+5 \alpha
$$

$\alpha=$ correction factor; $\alpha=0.000515$ (Diarov et al., 1990).

Table 2 Variation with time of TSE and TSP of some of the studied residual oil samples

\begin{tabular}{llcccccc}
\hline $\begin{array}{l}\text { Residual } \\
\text { oil sample }\end{array}$ & & $\begin{array}{c}\text { 1st } \\
\text { measurement }\end{array}$ & 1 month & 2 months & 3 months & 1 year & 2 years \\
\hline H-Oil FO, & TSE, wt.\% & 0.04 & 0.12 & 0.06 & 0.15 & & \\
16.02.16 & TSP, wt.\% & 0.15 & 0.18 & 0.46 & 0.39 & & \\
H-Oil FO, & TSE, wt.\% & 0.02 & 0.02 & 0.04 & 0.03 & & \\
08.03.16 & TSP, wt.\% & 0.03 & 0.04 & 0.04 & 0.03 & & \\
VB FO, & TSE, wt.\% & 0.02 & & & & 0.03 & \\
05.15 & TSP, wt.\% & 0.03 & & & & 0.04 & \\
H-Oil IFP & TSE, wt.\% & 0.01 & & & & 0.01 \\
70\%/30\% & TSP, wt.\% & 0.01 & & & & \\
HCO & TSE, wt.\% & 0.21 & & 0.71 & & & \\
H-Oil ATB & TSP, wt.\% & 0.54 & & 0.99 & & & \\
20.05.16 & TSP & & & & \\
H-Oil VTB & TSE, wt.\% & 0.47 & 0.59 & 1.16 & & & \\
20.05.16 & TSP, wt.\% & 0.66 & 0.89 & 2.21 & & & \\
\hline
\end{tabular}


Table 3 Results from the analyses of the residual fuel oils based on the residue H-Oil hydrocracking from three different cargos

\begin{tabular}{lccc}
\hline Property & $\begin{array}{c}\text { Residual fuel oil } \\
\text { Cargo 1 }\end{array}$ & $\begin{array}{c}\text { Residual fuel oil } \\
\text { Cargo 2 }\end{array}$ & $\begin{array}{c}\text { Residual fuel oil } \\
\text { Cargo 3 }\end{array}$ \\
\hline Density at $15^{\circ} \mathrm{C}, \mathrm{g} / \mathrm{cm}^{3}$ & 0.9815 & 0.9845 & 0.9830 \\
Sulphur, wt.\% & 0.873 & 0.810 & 0.832 \\
TSE, wt.\% & 0.11 & 0.12 & 0.12 \\
TSP, wt.\% & 0.27 & 0.29 & 0.34 \\
TSA, wt.\% & 0.10 & 0.11 & 0.11 \\
Cleanliness (ASTM D470) & 5 & 5 & 5 \\
Compatibility (ASTM D470) & 5 & 5 & 5 \\
\hline
\end{tabular}

By the use of Rogel's correlation [equation (9)] to relate oil $\frac{H}{C}$ atomic ratio to oil solubility parameter, the solubility parameters of asphaltene and maltene fractions of the studied residual oils were estimated.

$$
\delta=35.87-10.477 \frac{H}{C}
$$

where

$\delta \quad$ solubility parameter, $\mathrm{MPa}^{1 / 2}$.

According to Gray (2015), a general principle for solubility relationships is that the solubility parameters of the solvent and the solute must be within $3 \mathrm{MPa}^{1 / 2}$ of each other to achieve reasonable dissolution. Consequently, sediment can be expected when the solubility parameter of the residual asphaltenes rises to more than $3 \mathrm{MPa}^{1 / 2}$ above that of the liquid phase in the reactor (Gray, 2015). The data in Table 4 show that the lowest difference between the solubility parameters of the maltenes and the asphaltenes for the studied residual oils is 5.0. Therefore, all studied residual oils should be considered colloidal unstable and prone to form sediments. One can see that different ratings for the colloidal stability are obtained when different approaches are employed. According to the CII, all studied residual oils should be stable, while based on the data for the difference between the solubility parameters of the maltenes and the asphaltenes all investigated residual oils should be unstable. However, based on the measured colloidal parameters S-value and SN three of the studied residual oils are colloidal stable. These are the straight run vacuum residual oils. By employing the oil compatibility model of Wiehe, three more residual oils H-Oil FO, 08.03.16, VB FO 05.15, and H-Oil IFP 70/30\% could also be considered colloidal stable since their $\mathrm{S}$-value $\geq 1.4$. 
Table 4 Physical and chemical properties of the residual oils under study

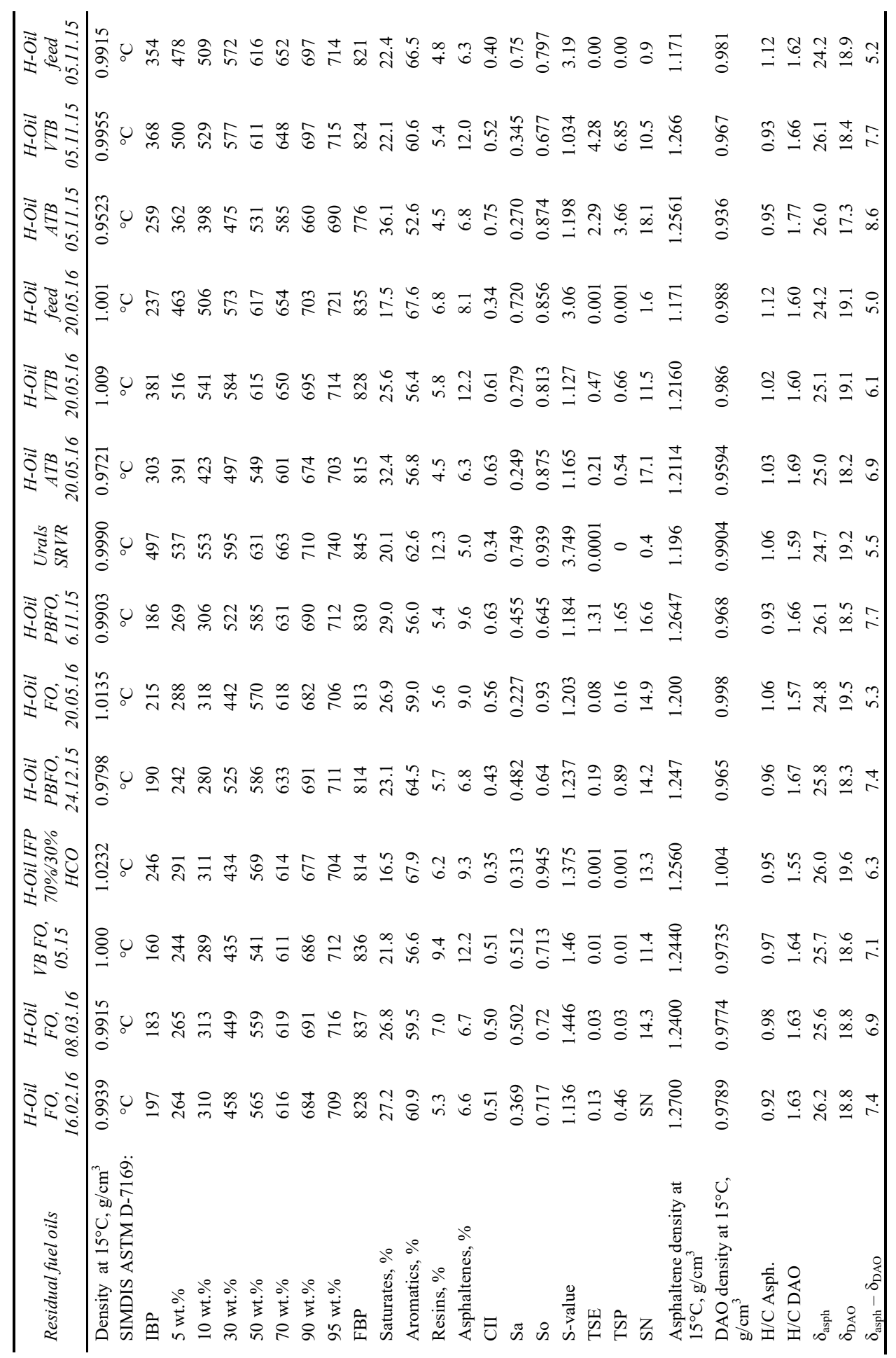


Table 5 Correlation matrix of the properties of the studied 14 residual oils

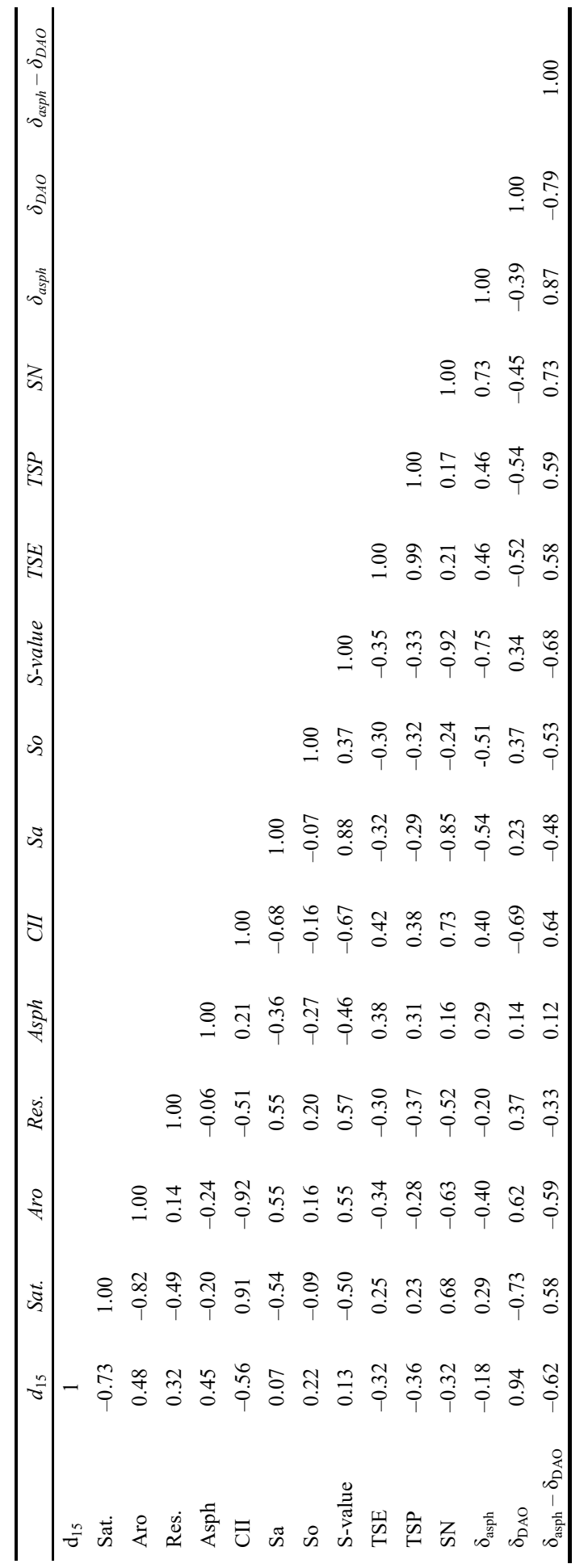


The data in Table 4 for hot filtration test before thermal aging (TSE), and after thermal aging (TSP) show that TSE varies between 0 and $4.28 \%$, while the TSP varies between 0 and $6.85 \%$. These data clearly indicate that after thermal aging the sediments go up. The graph in Figure 2 indicates that the TSP is 1.6 as high as the TSE for the studied residual oils. It should be noted here that the colloidal stable according to Wiehe's oil compatibility model residual oils H-Oil FO, 08.03.16, VB FO 05.15, and H-Oil IFP $70 / 30 \%$ did not exhibit increasing the HFT values after the thermal aging. This suggests that the thermal aging facilitates the processes of agglomeration of the particles for those residual oils which are colloidal unstable. In our earlier study, it was found that in the H-Oil residual oils obtained from the LNB H-Oil residue hydrocracker the sediments are formed mainly due to aggregation of the insoluble asphaltenes (Stratiev et al., 2016b). Therefore, a conclusion could be made that the thermal aging procedure favours further the processes of agglomeration of the aggregated insoluble asphaltenes in the H-Oil residual oils.

Figure 2 Relation of TSE to TSP of the residual oils under study (see online version for colours)

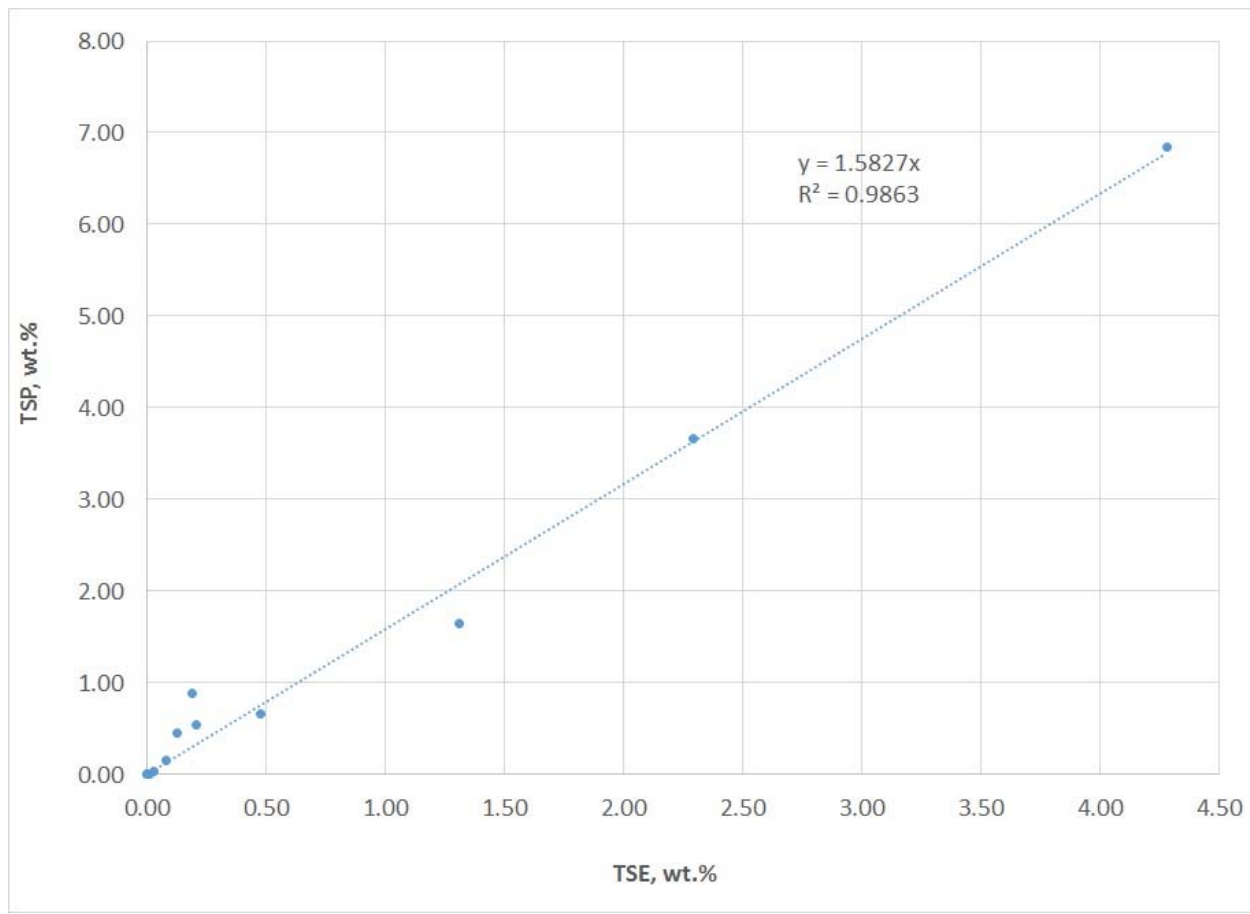

In order to understand the relations between the different residual oil colloidal stability parameters and the sediment content, a correlation matrix was made (Table 5). It is evident from the data in Table 5 that there are statistically meaningful relations between the colloidal stability parameters $\mathrm{S}$-value and $\mathrm{SN}(\mathrm{r}=-0.92)$, between $\mathrm{Sa}$ and S-value $(r=0.88)$, between Sa and SN $(r=-0.85)$, and between $S$-value and $\delta_{\text {Asph. }}$. $(\mathrm{r}=-0.75)$. These relations suggest that the colloidal stability of the studied residual oils depends mainly on the asphaltene solubility. The increase of asphaltene solubility (an increase of $\mathrm{Sa}$, and a decrease of $\delta_{\mathrm{Asph}}$.) obviously improves the colloidal stability of the residual oils. The data in Table 5 also indicate that none of the measured residual oil 
properties statistically meaningful correlates with TSE, and TSP. This suggests that in the case with the H-Oil residual oils the measurement of any of the colloidal stability properties S-value, SN, CII, and the difference between the solubility parameters of the asphaltene and maltenes cannot predict the H-Oil residual oil sediment content (TSE, TSP).

In the visbreaker, the unconverted visbroken residue S-value was found to correlate with the sediment content (Stratiev et al., 2014b). An attempt was made to find a similar relation of the S-value to the sediment content (TSE) of the unconverted VTB product from the LNB H-Oil hydrocracker by the use of data for VTB samples, whose properties were not included in Table 3. Figure 3 presents this attempt, showing no relation between the colloidal stability, quantified by the S-value, and the sediment content of the LNB H-Oil hydrocracker VTB product. It was also found that the other ASTM method for measuring the colloidal stability of heavy oils (ASTM D7061) by the use of SN did not correlate with the H-Oil VTB and ATB sediment content (Figure 4). The data in Figures 3 and 4 confirm that the colloidal stability parameters are not reliable indicators for evaluation of H-Oil unconverted VTB product propensity for sediment formation.

Bearing in mind that colloidal stability parameters S-value and SN failed to correlate with the H-Oil residual oil sediment content, some new indicator needed to be found to predict the sediment content in the H-Oil residues. Thereby, the decision was made to try a method that uses microscope and image analyser to calculate the surface area of the sediments. This method relates the microscope area of the sediment particles to the HFT and was tested on six H-Oil residual oil samples. Figure 5 shows a good correlation of the microscope area and the HFT. This method seems to be a promising option for H-Oil residual oil HFT monitoring, which features with a fast performance, unlike the HFT measurement. Additional investigations in this area are needed to prove the suitability of the microscope area to reliably substitute the HFT measurement.

Figure 3 Relation of S-value to sediment content in the ATB and VTB products from the LNB H-Oil unit (see online version for colours)

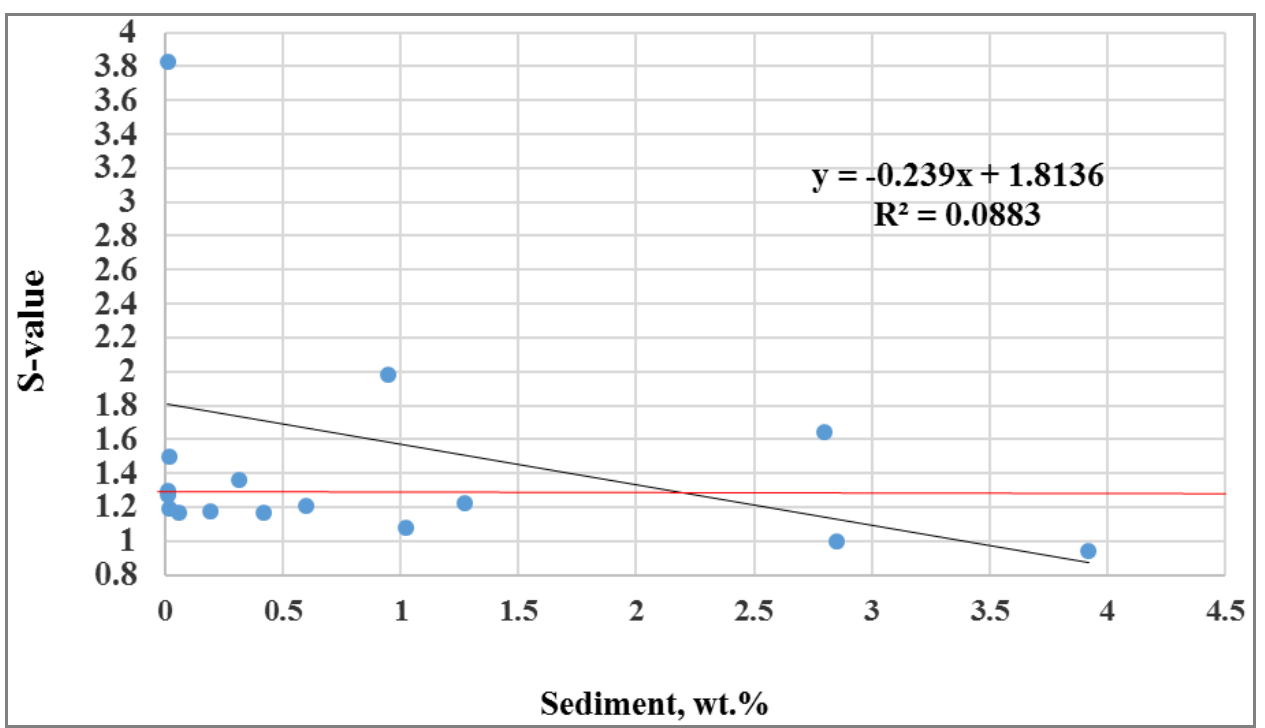


Figure 4 Relation of SN to sediment content in the VTB product from the LNB H-Oil unit (see online version for colours)

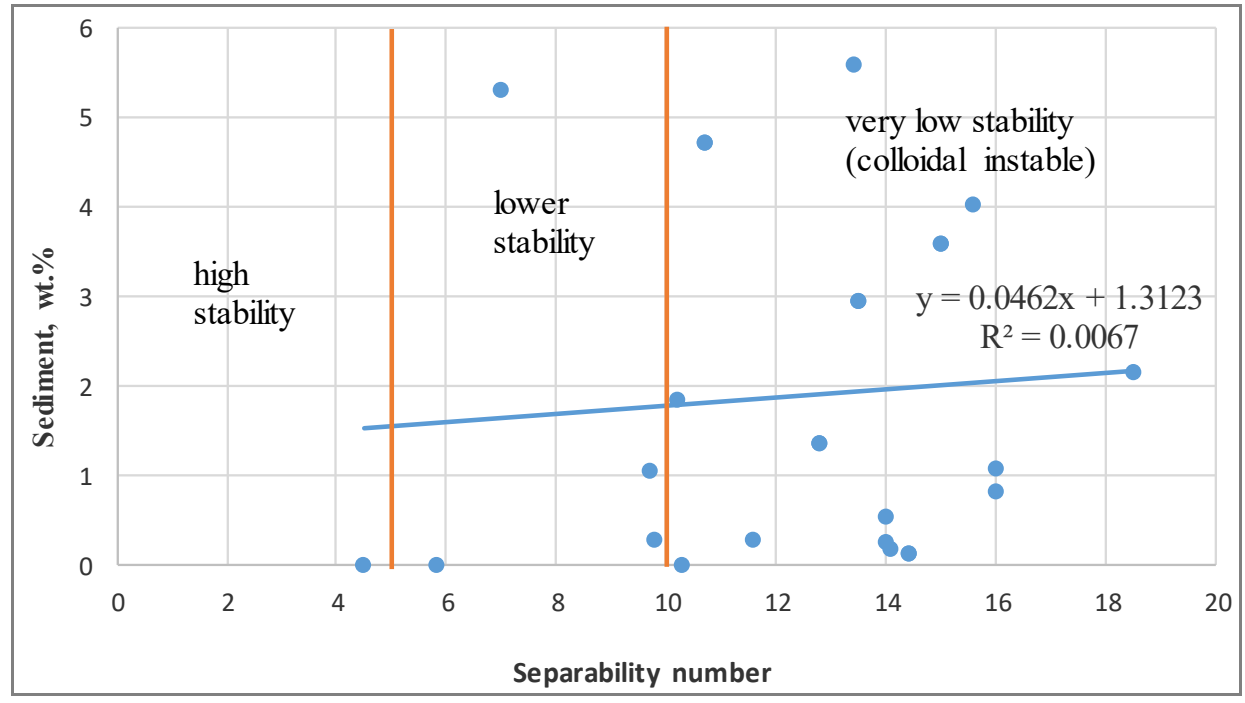

Figure 5 Relationship between the microscope surface area of the sediments and the H-Oil residual oil HFT (TSE) (see online version for colours)

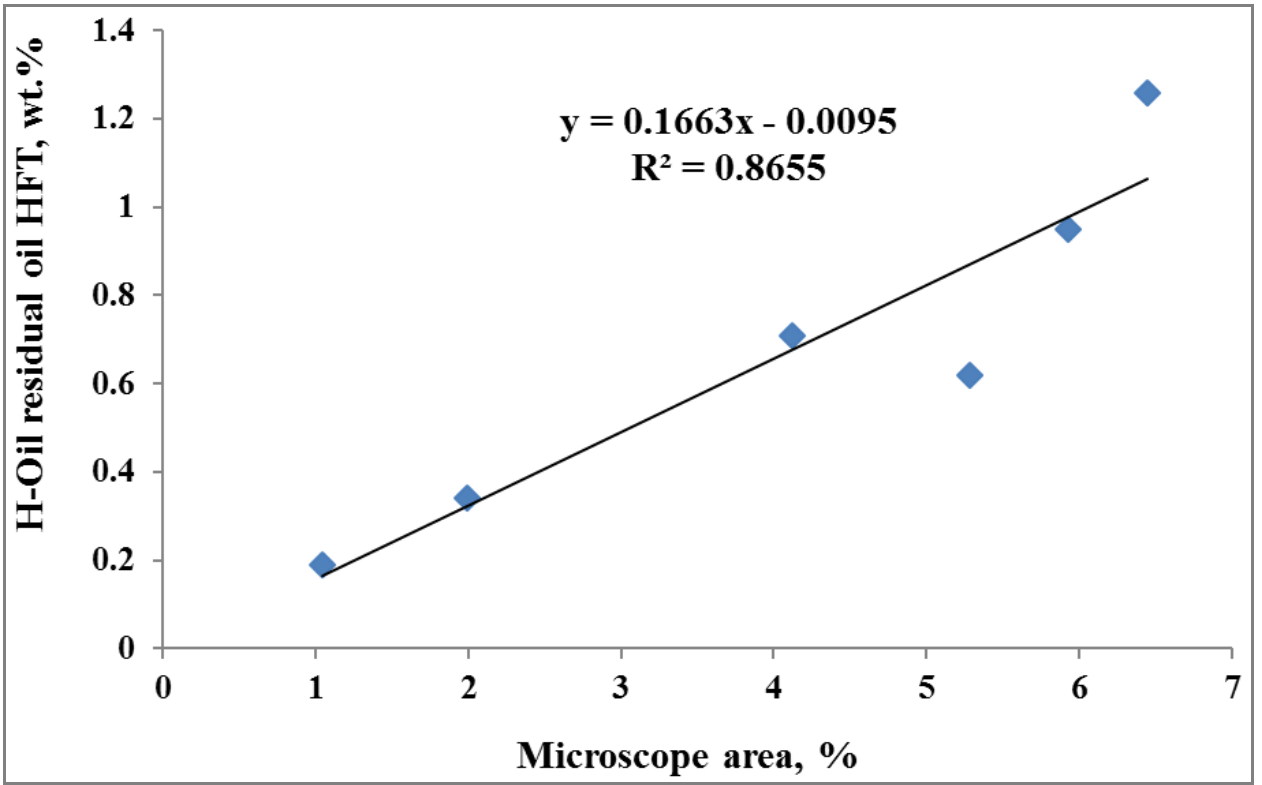

The failure of the colloidal stability parameters to predict the H-Oil residual oil sediment content might be explained by a possible formation of aggregates of asphaltenes during the vacuum residue hydroconversion. Having formed the aggregates in the reaction zone of the residue hydrocracker they cannot be dissolved downstream the reactors, and for that reason the devices measuring the colloidal stability of the H-Oil residual oils register 
instability since they detect the presence of aggregates having size of $500 \mathrm{~nm}$ and higher (Stratiev et al., 2014b, 2016b). These aggregates, however can be dispersed by the use of high aromatic diluents (Ortega et al., 2012; Marafi et al., 2005; Marques et al., 2011), and special additives (Kraiwattanawong et al., 2009), registering in this way a reduction in the HFT values. Therefore, the control of the HFT of the H-Oil residual oils, which is very important for keeping the health of the unit is much more informative than any of the measurable colloidal stability parameters. An application of a fast and a reliable tool to measure the HFT values of the H-Oil residual oils can be of great help for improving profitability of this high conversion bottom of the barrel process. While controlling the HFT of the residual oils in the H-Oil hydrocracker helps keep the good health of the unit, it cannot guarantee the production of residual fuel oil whose sediment content (TSE, TSP) will remain stable with the course of time. This study has shown that only the residual oil samples whose S-value was at minimum of $1.375 \mathrm{kept}$ their sediment contents without change with the course of time.

\section{Conclusions}

The performed investigation with 14 residual fuel oils based on $\mathrm{H}-\mathrm{Oil}$ residue hydrocracking and visbreaking allowed the following conclusions to be made:

1 The CII, estimated on the base of SARA analysis of the studied residual oils does not correlate with any other colloidal stability parameter explored in this work.

2 There is a statistically meaningful negative correlation between the colloidal stability parameters S-value (ASTM D7157) and SN (ASTM D7061).

3 The asphaltene solubility parameter statistically meaningful negatively correlates with the colloidal stability parameter S-value.

4 The colloidal stability of the studied residual oils depends mainly on the asphaltene solubility.

5 Both TSE and TSP do not correlate with any of the colloidal stability parameters of the studied residual oils. Neither S-value nor SN can be used to control sediment level in the H-Oil residual oils.

6 The microscope determined surface area of the sediments correlates with the H-Oil residue HFT. Additional investigations in this area are needed to prove the reliability of the correlation between the microscope determined surface area of the sediments and the H-Oil residual oils HFT.

7 The TSP for most H-Oil residual oils was 1.6 times as high as the TSE. It is very difficult to reduce the value of the TSP to that of the TSE since the mechanism of increasing the sediment content of the H-Oil residual oils after thermal aging is still unclear.

8 The residual fuel oils whose S-value is higher or equal to 1.375 regardless of the process used to produce them visbreaking or H-Oil do not show variation of sediment content with the course of time. 


\section{References}

American Society for Testing and Materials (ASTM D7157a) (2012) Standard Test Method for Determination of Intrinsic Stability of Asphaltene-Containing Residues, Heavy Fuel Oils, and Crude Oils (n-Heptane Phase Separation; Optical Detection), ASTM International, 100 Bar Harbor Drive, West Conshohocken, Pennsylvania 19428-2959, USA.

American Society for Testing and Materials (ASTM D7061b) (2012) Standard Test Method for Measuring n-Heptane Induced Phase Separation of Asphaltene-Containing Heavy Fuel Oils as Separability Number by an Optical Scanning Device, ASTM International, 100 Bar Harbor Drive, West Conshohocken, Pennsylvania 19428-2959, USA.

Andersen, S.I. (1999) 'Flocculation onset titration of petroleum asphaltenes', Energy \& Fuels, Vol. 13, No. 2, pp.315-322.

Asomaning, S. and Watkinson, A.P. (2000) 'Petroleum stability and heteroatom species effects in fouling of heat exchangers by asphaltenes', Heat Transfer Engineering, Vol. 21, No. 3, pp.10-16.

Bartholdy, J. and Andersen, S. (2000) 'Changes in asphaltene stability during hydrotreating', Energy \& Fuels, Vol. 14, No. 1, pp.52-55.

Deng, W., Luo, H., Gao, J. and Que, G. (2011) 'Stability change of asphaltene in the residue during slurry-phase hydrocracking', Energy \&Fuels, Vol. 25, No. 11, pp.5360-5365.

Diarov, I.N., Batueva, I.U., Sadikov, A.N. and Colodova N.L. (1990) Chemistry of Crude Oil, Chimia Publishers, St. Peterburg.

Evdokimov, I.N. (2010) 'The importance of asphaltene content in petroleum III - new criteria for prediction of incompatibility in crude oil blends', Petroleum Science and Technology, Vol. 28, No. 13, pp.1351-1357.

Faina, R., Ingrassia, M. and Zanotti, A. (1995) A Method for Determining an Instantaneous Reference Parameter of Tar Stability in a Thermal Conversion Oil Plant, Patent No. EP 0529397 B1, (published on 19.07.1995).

Gawel, I., Bociarska, D. and Biskupski, P. (2005) 'Effect of asphaltenes on hydroprocessing of heavy oils and residuals', Applied Catalysis A: General, Vol. 295, No. 1, pp.89-94.

Gray, M.R. (2015) Upgrading Oilsands Bitumen and Heavy Oil, The University of Alberta Press Ring House 2 Edmonton, Alberta, Canada.

Higuerey, I., Rogel, E. and Pereira P. (2001) 'Residue stability study in a thermal catalytic steam cracking process through theoretical estimation of the solubility parameter', Petroleum Science Technology, Vol. 19, Nos. 3-4, pp.387-401.

Hong, E. and Watkinson, P. (2004) 'A study of asphaltene solubility and precipitation', Fuel, Vol. 83, Nos. 14-15, pp.1881-1887.

Hong, E. and Watkinson, P. (2009) 'Precipitation and fouling in heavy oil-diluent blends', Heat Transfer Engineering, Vol. 30, Nos. 10-11, pp.786-793.

International Petroleum Test Methods (2011) IP 390-11 Petroleum Products - Total Sediments in Petroleum Residual Fuel Oils. Part 2 Determination using Standard Procedures for Aging, Energy Institute, 61 New Cavendish Street, London, W1G 7AR, UK.

Kraiwattanawong, K., Fogler, H.S., Gharfeh, S.G., Singh, P., Thomason, W.H. and Chavadej, S. (2009) 'Effect of asphaltene dispersants on aggregate size distribution and growth', Energy \& Fuels, Vol. 23, No. 3, pp.1575-1582.

Li, S., Liu, C., Que, G. and Liang, W. (1999) 'Colloidal structures of vacuum residua and their thermal stability in terms of saturate, aromatic, resin and asphaltene composition', Journal of Petroleum Science and Engineering, Vol. 22, Nos. 1-3, pp.37-45.

Marafi, M., Al-Barood, A. and Stanislaus, A. (2005) 'Effect of diluents in controlling sediment formation during catalytic hydrocracking of Kuwait vacuum residue', Petroleum Science. Technology, Vol. 23, Nos. 7-8, pp.899-908.

Marques, J., Maget, S. and Verstraete, J.J. (2011) 'Improvement of ebullated-bed effluent stability at high conversion operation’, Energy \& Fuels, Vol. 25, No. 9, pp.3867-3874. 
Matsushita, K., Marafi, A., Hauser, A. and Stanislaus, A. (2004) 'Relation between relative solubility of asphaltenes in the product oil and coke deposition in residue hydroprocessing', Fuel, Vol. 83, Nos. 11-12, pp.1669-1674.

Nikolaychuck, E., Veli, A., Stratiev, D., Shishkova, I., Burilkova, A., Tamahkiarova, E., Mitkova, M. and Yordanov, D. (2016) 'Physical vacuum distillation and high temperature simulated distillation of residual oils from different origin', accepted for publication in International Journal of Oil, Gas and Coal Technology.

Ortega, G.F., Mar-Juárez, E. and Hernández, P.H. (2012) 'Controlling sediments in the ebullated bed hydrocracking process', Energy\& Fuels, Vol. 26, No. 5, pp.2948-2952.

Rahimi, P., Gentzis, T., Chung, K., Nowlan, V. and DelBianco, A. (1997) 'Correlation of chemical composition of extra heavy oils with incipient coke formation using hot-stage microscopy' [online] https://web.anl.gov/PCS/acsfuel/preprint\%20archive/Files/42_1_SAN\% 20FRANCISCO_04-97_0146.pdf (accessed 16 June 2016).

Redelius, P.G. (2000) 'Solubility parameters and bitumen', Fuel, Vol. 79, No. 1, pp.27-35.

Robert, E., Merdrignac, I., Rebours, B., Harle, V., Kressmann, S. and Colyar, J. (2003) 'Contribution of analytical tools for the understanding of sediment formation: application to H-Oil ${ }^{\circledR}$ process', Petroleum Science Technology, Vol. 21, Nos. 3-4, pp.615-627.

Rogel, E. (1998) 'Theoretical approach to the stability of visbroken residues', Energy \& Fuels, Vol. 12, No. 5, pp.875-880.

Russell, C.A., Crozier, S. and Sharpe, R. (2010) 'Observations from heavy residue pyrolysis: a novel method to characterize fouling potential and assess antifoulant additive performance', Energy \& Fuels, Vol. 24, No. 10, pp.5483-5492.

Sadeghi-Yamchi, H. (2014) Effect of Refining on Asphaltene Property Distributions, published $\mathrm{PhD}$ thesis, University of Calgary [online] http://theses.ucalgary.ca/jspui/handle/11023/1619 (accessed 20 June 2016).

Saleh, Z.S., Sheikholeslami, R. and Watkinson, A.P. (2005) 'Blending effects on four crude oils', Paper presented at the 6th International Conference on Heat Exchanger Fouling and Cleaning - Challenges and Opportunities, ECI Symposium Series, Kloster Irsee, Germany, 5-10 June, Vol. RP2.

Sharpe, R. (2010) 'Visbreaker optimization program', Presented in LUKOIL Neftohim Burgas Refinery, 29 March.

Shimizu, K., Uehara, J. and Hayashi, T. (2000) 'Current studies on stability and combustibility of marine fuel oil', Bulletin of the M.E.S.J., p.28.

Stanislaus, A., Hauser, A. and Marafi, M. (2005) 'Investigation of the mechanism of sediment formation in residual oil hydrocracking process through characterization of sediment deposits', Catalysis Today, Vol. 109, Nos. 1-4, pp.167-177.

Stratiev, D., Belchev, Z., Petkov, P. and Kirilov, K. (2008) 'Investigation on residual fuel oil stability', Oil Gas European Magazine, Vol. 34, No. 4, pp.199-203.

Stratiev, D., Shishkova, I., Nikolova, R., Tsaneva, T., Mitkova, M. and Yordanov D. (2016a) 'Investigation on precision of determination of SARA analysis of vacuum residual oils from different origin', Petroleum \& Coal, Vol. 58, No. 1, pp.109-119.

Stratiev, D., Dinkov, R., Shishkova, I., Sharafutdinov, I., Ivanova, N., Mitkova, M., Yordanov, D., Rudnev, N. and Stanulov, K. (2016b) 'What is behind the high values of hot filtration test of the ebullated bed residue H-Oil hydrocracker residual oils?', Energy \& Fuels, Vol. 30, No. 9, pp.7037-7054.

Stratiev, D., Shishkova, I., Tsaneva, T., Mitkova, M. and Yordanov, D. (2016c) 'Investigation of relations between properties of vacuum residual oils from different origin, and of their deasphalted and asphaltene fractions', Fuel, Vol. 170, pp.115-129.

Stratiev, D., Nedelchev, A., Shishkova, I., Ivanov, A., Sharafutdinov, I., Nikolova, R., Mitkova, M., Yordanov, D., Rudnev, N., Belchev, Z., Atanassova, V. and Atanassov, K. (2015) 'Dependence of visbroken residue viscosity and vacuum residue conversion in a commercial visbreaker unit on feedstock quality', Fuel Processing Technology, Vol. 138, pp.595-604. 
Stratiev, D., Shishkova, I., Dinkov, R., Nedelchev, A., Marinov, I., Bonchev, I., Obryvalina, A., Telyashev, R., Nikolova, R. and Mitkova, M. (2014a) 'Current technology solutions in modern refining business', Oil and Gas Chemistry, Vol. 1, No. 1, pp.1-24.

Stratiev, D., Shishkova, I., Dinkov, R., Nikolova, R., Mitkova, M., Stanulov, K., Sharpe, R., Russell, C., Obryvalina, A. and Telyashev, R. (2014b) 'Reactivity and stability of vacuum residual oils in their thermal converse', Fuel, Vol. 123, No. 1, pp.133-142.

Tojima, M., Suhara, S., Imamura, M. and Furuta, A. (1998) 'Effect of heavy asphaltene on stability of residual oil', Catalysis Today, Vol. 43, Nos. 3-4, pp.347-351.

Wang, J., Li, C., Zhang, L., Deng, W. and Que, G. (2009) 'Phase separation and colloidal stability change of Karamay residue oil during thermal reaction', Energy \& Fuels, Vol. 23, No. 6, pp.3002-3007.

Watkinson, P. (2007) 'Deposition from crude oils in heat exchangers', Heat Transfer Engineering, Vol. 28, No. 3, pp.177-184.

Wiehe, I.A. (2004) 'Self-incompatible crude oils and converted petroleum resids', Journal of Dispersion Science and Technology, Vol. 25, No. 3, pp.333-339.

Zerlia, T. and Pinelli, G. (1993) 'Stability-related tests on visbreaking residues obtained at increasing severity', Fuel, Vol. 72, No. 8, pp.1109-1114.

Zhang, L., Yang, G., Que, G., Zhang, Q. and Yang, P. (2006) 'Colloidal stability variation of petroleum residue during thermal reaction', Energy \& Fuels, Vol. 20, No. 5, pp.2008-2012. 